\title{
Sound production in two carapids (Carapus acus and C. mourlani) and through the sea cucumber tegument
}

\author{
Eric Parmentier, ${ }^{1}$ Michael Fine ${ }^{2}$ Pierre Vandewalle, ${ }^{1}$ Jean-Jacques Ducamp ${ }^{3}$ and Jean-Paul Lagardère ${ }^{4}$
}

\author{
${ }^{1}$ Laboratoire de Morphologie Fonctionnelle \\ et Evolutive, Institut de chimie, Bât. B6, \\ Université de Liège, B-4000 Liège, \\ Belgium; ${ }^{2}$ Department of Biology, Virginia \\ Commonwealth University, Richmond, \\ VA 23284-2012, USA; ${ }^{3}$ Centre d'Etude \\ Biologiques de Chizé, CNRS, 79360 \\ Villiers-en-Bois, France; ${ }^{4}$ CREMA- \\ L'Houmeau (CNRS-Ifremer), BP 5, 17137 \\ L'Houmeau, France
}

Keywords:

Carapidae, soniferous, swimbladder

Accepted for publication:

9 January 2006

\begin{abstract}
Parmentier, E., Fine, M., Vandewalle, P., Ducamp, J.-J. and Lagardère, J.-P. 2006. Sound production in two carapids (Carapus acus and C. mourlani) and throught the sea cucumber teguments. - Acta Zoologica (Stockholm) 87: 113-119

Carapus acus and Carapus mourlani are able to live inside sea cucumbers and sea stars respectively. Unlike other carapids whose sounds have been recorded (C. boraborensis, C. homei and Encheliophis gracilis), these two species have a central constriction in their swimbladder and are unlikely to encounter heterospecific carapids within their hosts. We evoked sound production in Carapus acus and Carapus mourlani by adding several individuals to a tank with a single host and found that their sounds differ substantially from the sounds emitted by other carapids in pulse length, peak frequency and sharpness of tuning $\left(Q_{3 \mathrm{~dB}}\right)$. Unlike the other carapids, C. mourlani and $C$. acus produce shorter and less repetitive sounds and do not produce sounds when they enter their host. Since sounds produced within a sea cucumber have the potential to be heard by distant carapids and are typically recorded outside the sea cucumber, we examined the effect of the sea cucumber tegument on acoustic transmission. Attenuation by the tegument was negligible at the frequencies within carapid sounds. Therefore, carapids have the potential to call from the relative safety of a sea cucumber without sacrificing the distance over which their transmissions are heard.
\end{abstract}

Eric Parmentier, Laboratoire de Morphologie Fonctionnelle et Evolutive, Institut de chimie, Bât. B6, Université de Liège, B-4000 Liège, Belgium. E-mail: e.parmentier@ulg.ac.be

\section{Introduction}

Some pearlfish (Carapidae) enter and reside in invertebrate hosts such as sea stars, sea cucumbers or bivalves (e.g. Trott 1981; Parmentier and Vandewalle 2005). The host reduces visual, chemical or tactile perception of both predators and congeners. The ability to communicate acoustically would be an advantage during host colonization and reproduction, and three species have been shown to produce speciesspecific sounds (Parmentier et al. 2003a). Sounds have only been recorded when an individual has entered a sea cucumber that was already occupied.

In areas of the Pacific Ocean where they live in sympatry (Markle and Olney 1990), Carapus boraborensis, C. homei and Encheliophis gracilis can inhabit the same host species but heterospecifics are rarely found together in the same host
(Smith 1964; Trott 1970; Trott and Trott 1972; Vanden Spiegel and Jangoux 1989). Of 257 Bohadschia argus collected in Opunohu Bay (Moorea, French Polynesia), $83 \%$ contained different species of carapids but less than $1 \%$ included heterospecific infestations (Parmentier and Vandewalle 2005). Laboratory experiments and field studies revealed that the fish do not appear to determine whether a potential host is already occupied; the fish penetrates the first host it contacts. However, when C.boraborensis and C. homei are inside the same holothurian, the interspecific confrontation is accompanied by short sound signals. Intraspecific confrontations are associated with longer and prolonged sounds. Interestingly, the first acoustic signals are emitted as the inter- or intraspecific types without passing through an intermediate enquiry-type stage (Lagardère et al. 2005). 
The apparent silence of fish approaching a host is not understood. Since these species are capable of eating each other, it could be advantageous to be discrete. However, the meeting of two species does not automatically end in predation because one of the fish may leave the host (Parmentier and Vandewalle 2005). Therefore, the entering fish appears to be willing to risk an encounter to allow it to assess the size of any other fish that might be present.

The carapid sonic mechanism includes specialized anterior vertebrae, the swimbladder and associated muscles (Courtenay and McKittrick 1970; Markle and Olney 1990; Parmentier et al. 2000; Parmentier \& Vandewalle 2003). The anteriormost lateral surface of the swimbladder possesses a horseshoe-shaped thinner zone, the swimbladder fenestra. The fenestra is covered dorsolaterally by the swimbladder plate, an extension of the third epineural rib. The sonic muscles originate on the orbital roof of the skull and insert into the anterior wall of the swimbladder (Parmentier et al. $2003 b$ ). The action of the sonic muscles in sound generation could stimulate movement of the fenestra (Parmentier et al. 2003a, 2003b), which presses against the swimbladder plate. The swimbladder plate is broader, thinner and more regularly shaped in the Carapini tribe (Encheliophis and Carapus) than in free-living carapids. Parmentier et al. (2002) suggested that the large swimbladder plate of the Carapini could be related to their way of life because the teguments of the host could disturb or attenuate sound propagation.

On the other hand, the genus Carapus can be divided into two subgroups: subgroup 1 (C. acus, C. bermudensis and C. mourlani) possesses a central constriction of the swimbladder (Fig. 1), which is not present in subgroup 2 (C. homei, C. boraborensis and C. dubius). Moreover, fishes of subgroup 1 can only have conspecific encounters in their host whereas they can be heterospecifics for C. homei and C. boraborensis (Markle and Olney 1990; Parmentier et al. 2000).

The goal of this study was dual. (1) The sounds of $C$. acus and $C$. mourlani were recorded for the first time and compared

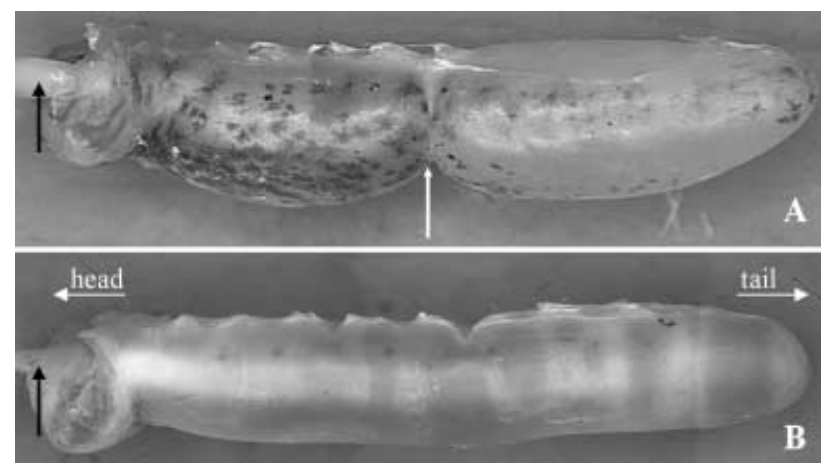

Fig. 1-Left lateral view of the swimbladder. -A. In Carapus mourlani-B. In C. boraborensis. White arrow: central constriction of the swimbladder. Black arrow: localization of the sound-producing muscle. with previously recorded species (C. boraborensis, C. homei and $E$. gracilis) to know (i) how the central constriction of the swimbladder can influence the sound and (ii) if the differences in the ecology of both groups can be inferred from the sounds produced. (2) In the second experiment, the goal was to know if the tegument of the sea cucumber host could (or could not) disturb the propagation of sounds.

Carapus mourlani is commonly found in the Indo-Pacific as a commensal of sea stars such as Culcita sp. and Acanthaster planci (Meyer-Rochow 1977, 1979; Trott 1981; Eeckhaut et al. 2004). Carapus mourlani has been observed to swim along the ambulacral groove of the sea star Culcita before entering the stomach, tail first, through the oral cavity and finally reaching the general cavity (E. Parmentier, personal observation). Carapus acus lives in the Mediterranean Sea and on the east coast of North Africa. It is usually found in the sea cucumbers Stichopus regalis, Holothuria tubulosa and Holothuria stellati, which it enters tail first or head first (Kloss and Pfeiffer 2000; Eeckhaut et al. 2004).

\section{Materials and methods}

\section{Carapus mourlani}

Thirty-two C. mourlani (total length $6-10 \mathrm{~cm}$ ) were collected by scuba diving in the lagoon in front of Tulear (Mozambic canal, west coast of Madagascar) in June 2004. They were found in the general body cavity of the sea star Choriaster granulatus $(n=40)$. Host and fish were stored in a community tank $(3.50 \times 0.7 \times 0.2 \mathrm{~m})$ with running sea water. Recordings were made at $26^{\circ} \mathrm{C}$ in a smaller tank $(1 \times 0.5 \times 0.6 \mathrm{~m})$. A specimen of the host was placed in the centre of the tank, and several individuals were introduced successively into the aquarium. Sounds were recorded with an Orca hydrophone (sensitivity: $-186 \mathrm{~dB}$ re $1 \mathrm{~V} / \mu \mathrm{Pa}$ ) connected via an Orca-made amplifier (ORCA Instrumentation, France) to a mini-disc recorder (JVC, XM-228BK). This system has a flat frequency response range $( \pm 3 \mathrm{~dB})$ between 10 and $23.8 \mathrm{kHz}$. The hydrophone was placed above the sea star.

\section{Carapus acus}

Thirty-two C. acus (total length of 8-12 cm) were collected from dissection of 87 Holothuria tubulosa and 129 Holothuria stellati obtained in front of the STA.RE.SO station (Calvi Bay, Corsica) in April 2004. Fish were stored in a community tank $(0.6 \times 0.6 \times 0.4 \mathrm{~m})$ with running sea water. Recordings were made at $19{ }^{\circ} \mathrm{C}$ in a smaller tank $(0.4 \times 0.4 \times 0.31 \mathrm{~m})$. A specimen of the host $(H$. stellati) was first placed in the centre of the tank, and several individuals were introduced successively into the aquarium. Sounds were recorded with an HTI 16400 hydrophone coupled with a preamplifier and connected to a Sony TCD-D8 digital audio tape-recorder (recording band width: $20-22000 \mathrm{~Hz} \pm 1.0 \mathrm{~dB}$ ). 


\section{Low frequency generator}

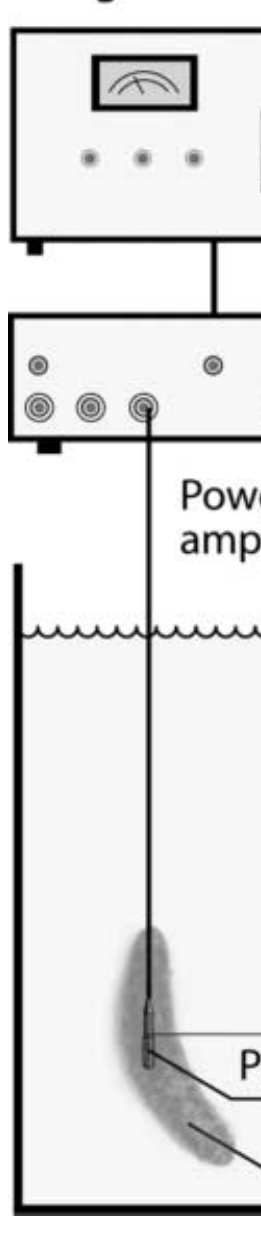

\section{Sound analysis}

Sounds were digitized at $44.1 \mathrm{kHz}$ (16-bit resolution) and analysed with AVISSOFT-SAS LAB PRO 4.33 software (1024-point Hanning windowed FFT). The resonant frequencies of the tanks were calculated as 2.56 and $3.58 \mathrm{kHz}$ respectively using an equation from Akamatsu et al. (2002), and low-pass filters of $2.56 \mathrm{kHz}$ and $3.58 \mathrm{kHz}$ were applied to the sounds of Madagascar and Calvi respectively. Temporal features were measured from the oscillograms, and frequency parameters were obtained from power spectra (filter band width $300 \mathrm{~Hz}$, FFT size 256 points, time overlap 96.87\% overlap, and a Hamming window). The following sound parameters were measured: sound duration; number of peaks per pulse; dominant frequency and $Q_{3 \mathrm{~dB}}$, i.e. the quotient of the dominant frequency divided by the band width $3 \mathrm{~dB}$ down from the peak frequency.

\section{Attenuation of sounds by the sea cucumber tegument?}

To determine the effect of the sea cucumber tegument on acoustic transmission, a set of experiments was conducted in

\section{Projector}

\section{Third octave band pass filter 1618}

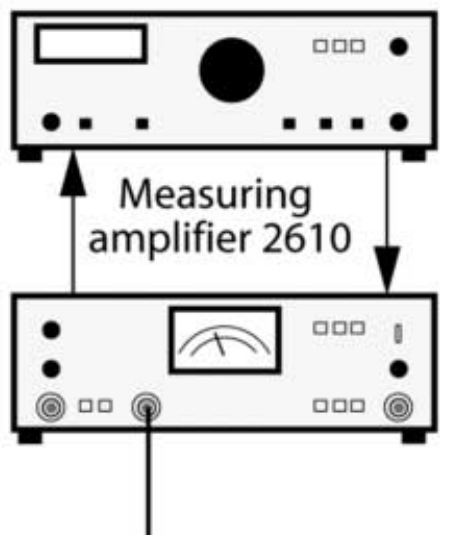

\section{Receiver}

a large glass aquarium $(2.48 \times 0.7 \times 0.7 \mathrm{~m})$ (Fig. 2). A 8103

Brüel \& Kjaer is used as a constant sound pressure transmitter, and a B \& K, type 8101 hydrophone was the receiver. Tones from a frequency generator were fed into the transmitting hydrophone via a low distortion power amplifier. The signal from the receiver hydrophone was conditioned and amplified in a measuring amplifier (B \& K, type 2610). With a meter scale (B \& K, SA 0251) calibrated to the 8101 hydrophone sensitivity, the measuring amplifier coupled with a third octave band pass filter (B \& K, type 1618) was used as a sound level meter to measure the ambient noise in the aquarium.

The transmitting hydrophone was fed into the cloacal cavity of the sea cucumber $(H$. stellati) collected from the same area as $C$. acus, and the measuring hydrophone was placed at a distance of $25 \mathrm{~cm}$. An equivalent set of measurements was made with the transmitting hydrophone in the identical position with the sea cucumber removed. Any difference between the two sets of measurements reflects attenuation by the tegument of the sea cucumber. Measurements were repeated five times with five different sea cucumbers, and values for 

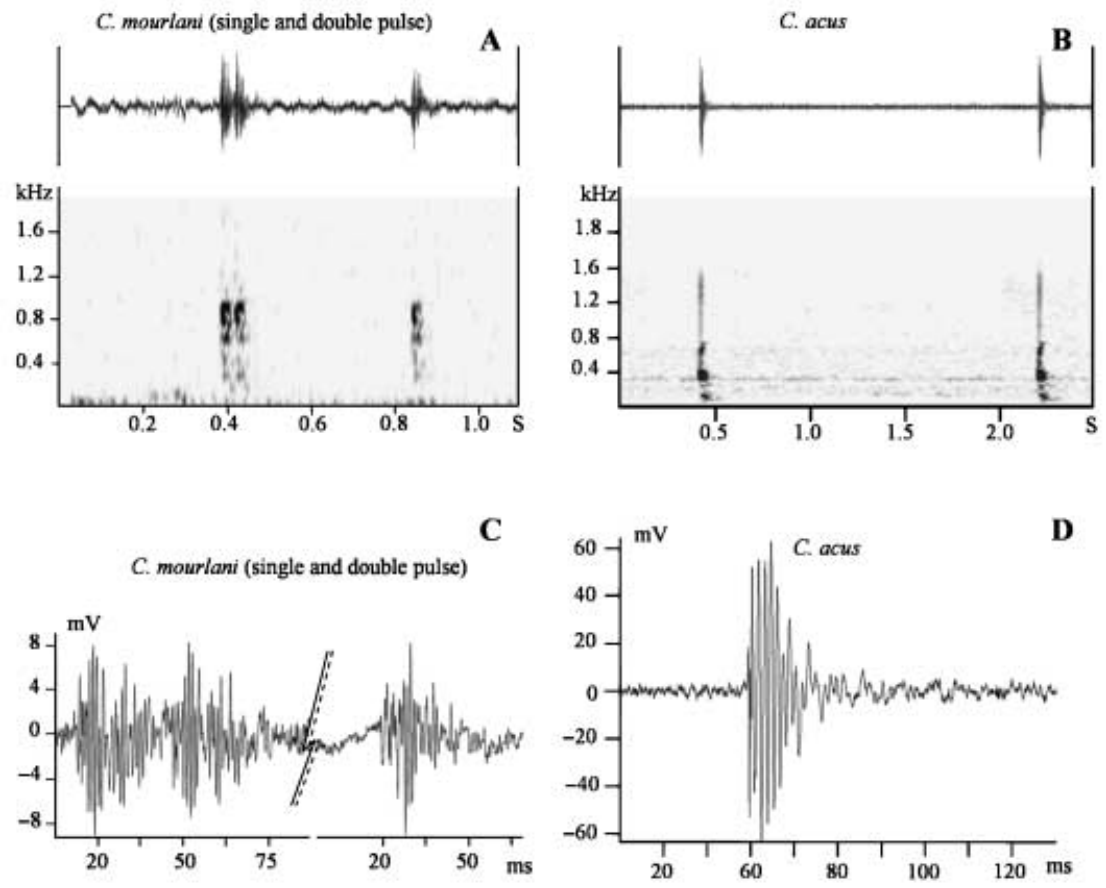

Fig. 3-A, B. Sonograms of pulses in Carapus mourlani and Carapus acus.

-C, D. Oscillograms of pulses in Carapus mourlani and Carapus acus. each frequency were averaged. Ambient noise was measured in each experiment and averaged.

\section{Results}

\section{Description of sounds}

Carapus mourlani produced single- and double-pulsed calls when competing for access to the oral aperture of the sea star. However, no sound was recorded once different fishes were in the host.

Single pulses (Fig. 3) had an average duration of $15.5 \pm$ 5 ms (mean \pm SD) and contained $11-20$ peaks (mean \pm SD, $16 \pm 5$ ). Peak frequency was $638 \pm 167 \mathrm{~Hz}$ (Fig. 3A), and most sound energy ranged from about 570 to $1000 \mathrm{~Hz} . Q_{3 \mathrm{~dB}}$ averaged $4 \pm 3$.

Each unit of the double pulse (Fig. 3C) appeared to consist of an initial and a later energy peak: the sound amplitude built up, decayed and then increased to a second although smaller set of peaks within a pulse. Double pulses had an average duration of $54.4 \pm 2.1 \mathrm{~ms}$, and an interpulse interval of $9.26 \pm 2.2 \mathrm{~ms}$. Each pulse ranged from 16.2 to $29.3 \mathrm{~ms}$ (mean $\pm \mathrm{SD}, 22 \pm 4.2$ ) and contained $10-20$ peaks (mean $\pm S D$, $16 \pm 5$ ). Peak frequency was $765 \pm 124 \mathrm{~Hz}$, and most sound energy ranged from about 210 to $1070 \mathrm{~Hz} . Q_{3 \mathrm{~dB}}$ averaged $4 \pm 1.38$. However, the pulses of both calls differed significantly only in their pulse length $(P<0.005)$. Therefore double pulses appeared to be a repetition of the single pulse (Fig. 3C).

Carapus acus produced sounds when the fish swam in the aquarium without any discernable interactions between fishes. Sounds were not produced during or after penetration of the host. Sounds were composed of a single pulse of 1213 peaks (Fig. 3D) with an average duration of $34.8 \mathrm{~ms}$. Peak frequency was $341 \pm 4.05 \mathrm{~Hz}$, and most sound energy ranged from about 250 to $1600 \mathrm{~Hz}$ (Fig. 3B). $Q_{3 \mathrm{~dB}}$ averaged $8 \pm 1.32$.

\section{Sea cucumber attenuation}

Background noise in the tank decreased by about $8 \mathrm{~dB}$ from a mean of $66.8 \mathrm{~dB}$, re 1 (micro-pascal) $\mu \mathrm{Pa}$ at $200 \mathrm{~Hz}$ to $58.4 \mathrm{~dB}$ at $1000 \mathrm{~Hz}$ (Fig. 4). The decrease in background noise over the range of recorded frequencies was the result of sound absorption by sea water; the higher the frequency, the greater the attenuation (Wenz 1962).

The $200-\mathrm{Hz}$ tone was above background by slightly over $2 \mathrm{~dB}$, but other frequencies had a margin of at least $7.5 \mathrm{~dB}$. The tegument of the sea cucumbers ranged between 5 and $12 \mathrm{~mm}$ in thickness and did not affect results. Differences between sound pressure level with the transmitter inside the sea cucumber and free in the water averaged $0.3 \mathrm{~dB}$ (Fig. 4) indicating that the sea cucumber had a negligible effect on transmission of carapid acoustic signals.

\section{Discussion}

This study describes sound production in C. mourlani and C. acus, species with a constriction in the swimbladder, and indicates that differences exist between their sound and sounds previously described for C. boraborensis, C. homei and 


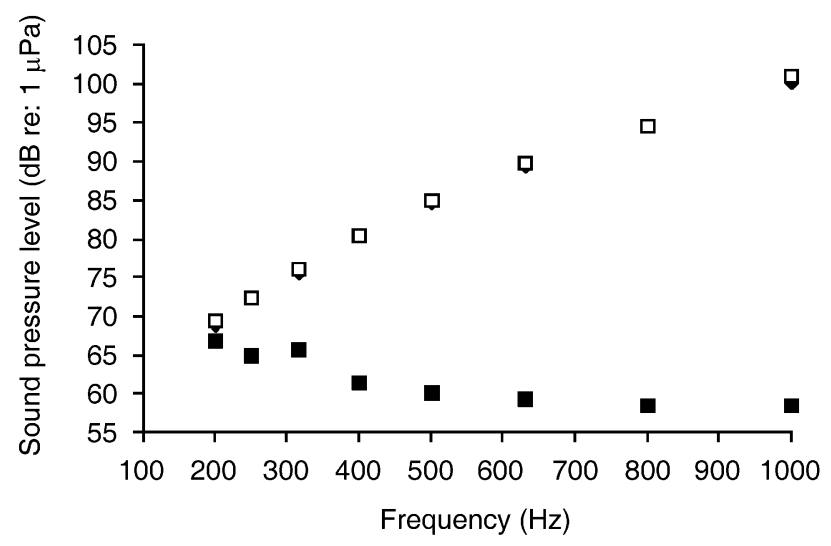

Fig. 4 - Sound pressure level recorded $25 \mathrm{~cm}$ from a transmitting hydrophone emitting tone burst outside $(\bullet)$ or inside $(\square)$ the sea cucumber (Holothuria stellati). Ambient noise (ם) was measured with third-octave filters. Numbers represent the mean of five trials with five different sea cucumbers. Sounds recorded inside $(\square)$ and outside ( ) the sea cucumber are essentially overlapping.

E. gracilis (Parmentier et al. 2003a; Lagardère et al. 2005) (Table 1). Carapus boraborensis produces long sequences (25-30 s sound duration) of regular drum beats. These sounds are composed of trains of 11-30 pulses, with each pulse lasting between 80 and $140 \mathrm{~ms}$. Carapus homei produces mainly brief sequences (3-5 s) of a slow regular beat on a 'metal' drum skin although in some cases double pulses are produced. The average length of these pulses is $220 \mathrm{~ms}$. Encheliophis gracilis produces either single beats or drum rolls of less than $1 \mathrm{~s}$ duration. The pulse duration of single beats borders $362 \mathrm{~ms}$.

Differences between carapids in this study and C. boraborensis, $C$. home $i$ and E. gracilis lie in the pulse length, dominant peak frequency and the $Q_{3 \mathrm{~dB}}$; the pulse length, on average, is between 16 and $35 \mathrm{~ms}$ whereas it is between 83 and $362 \mathrm{~ms}$ in C. boraborensis, C. homei and E. gracilis (Parmentier et al. 2003a; Lagardère et al. 2005) and, values of $Q_{3 \mathrm{~dB}}$ are, respectively, between 4 and 8 in the first group, around 12 in C. homei and 15 in C. boraborensis (Parmentier, unpublished data). Peak frequency is between 300 and $800 \mathrm{~Hz}$ in C. acus and C.mourlani, whereas maximum sound energy was between 40 and $80 \mathrm{~Hz}$ for E. gracilis, between 80 and $160 \mathrm{~Hz}$ for C. boraborensis and between 90 and $280 \mathrm{~Hz}$ for C. homei (Parmentier et al. 2003a).

Carapus acus and C. mourlani of this study were smaller than the three other carapids, which ranged from 80 to $300 \mathrm{~mm}$ in total length (TL) (Parmentier et al. 2003a). The smaller size may relate to their shorter pulse length and the higher dominant peak frequency. Relationships between size and pulse length and peak frequency have been found in catfish (Fine and Ladich 2003), weakfish (Connaughton et al. 2000), damselfish (Myrberg et al. 1993; Lobel and Mann 1995) and gouramis (Ladich et al. 1992): the pulse duration increases and dominant frequency decreases in larger fish. Although frequency can vary over several hundred hertz in differently sized fish of the same species, it is unlikely that fish size alone could explain the difference in pulse length among carapids. How the central constriction (Fig. 1) in the swimbladder in C. acus and C. mourlani affects sound emission is unknown but it could conceivably increase the natural frequency of the anterior part of the swimbladder. Tuning is also less sharp (i.e. $Q_{3 \mathrm{~dB}}$ values are smaller) in these species, but it is not immediately apparent how the central constriction would affect this parameter. $Q_{3 \mathrm{~dB}}$ in croaker Micropogonius chromis is about 3 (Fine et al. 2004), which is considerably less than in any of the carapids. The croaker has a sonic muscle-swimbladder mechanism without the skeletal specializations that are present in carapids and is likely to represent a more typical tuning for a sonic teleost bladder. Parmentier and Vandewalle (2003) suggested that the swimbladder plate could function as a resonator. If the plate is set into motion by the sonic muscles and then functions to drive swimbladder vibrations, the tuning of the plate could explain the high $Q$ tuning of carapid sounds.

Carapus mourlani and C. acus, unlike C. homei, C. boraborensis and E. gracilis, do not produce sounds when they enter their host. Carapus acus is the only symbiotic carapid found in Corsica, and C. mourlani is a commensal in sea cucumbers that do not host other carapids (Markle and Olney 1990; Parmentier et al. 2006). However, C. mourlani is found in sea stars (Eeckhaut et al. 2004) in locations that are sympatric with other symbiotic carapid species (C. boraborensis, $C$. homei and E. gracilis) but appears to avoid contact with other carapid species. In contrast C. boraborensis, C. homei and E. gracilis are usually found in the same species of sea cucumber

Table 1 Description of sounds made by different carapids

\begin{tabular}{|c|c|c|c|c|c|c|}
\hline & Sound duration (s) & No. pulses/train & Pulse period (ms) & Pulse duration (ms) & Dominant peak frequency $(\mathrm{Hz})$ & $Q_{3 \mathrm{~dB}}$ \\
\hline Encheliophis gracilis & $<1$ & $1-2$ & - & 362 & 60 & - \\
\hline Carapus homei & $3-5$ & $2-10$ & 334 & 220 & $90-280$ & 12 \\
\hline Carapus boraborensis & $3-30$ & $11-30$ & $180-212$ & $80-140$ & $80-200$ & 15 \\
\hline Carapus acus & 0.035 & 1 & - & 35 & 341 & 8 \\
\hline Carapus mourlani & $0.015-0.055$ & $1-2$ & $8-12$ & $16-30$ & $638-765$ & 4 \\
\hline
\end{tabular}


(Parmentier et al. 2000; Eeckhaut et al. 2004; Parmentier and Vandewalle 2005), and interspecific contact is likely. Since an individual entering a sea cucumber that is already inhabited by the same or a different species can lead to eviction or death (Parmentier and Vandewalle 2005; Lagardère et al. 2005), it would be adaptive to produce repetitive calls. This constraint is apparently removed in C.acus and C. mourlani because they have no chance of encountering another fish species in the host.

The brief sequences emitted by these two species may be associated with the spawning period. In many teleost species, sound production is linked to the spawning season because sounds may have a role in female choice and timing of gamete release (Hawkins 1993; Zelick et al. 1999; Hawkins and Amorim 2000). The spawning period appears to occur from July to September in C. acus but is unknown for C. mourlani (Trott and Olney 1986). Fish were recorded in June, and the short pulses were produced close to the assumed reproductive period. Moreover, at the end of October, 24 specimens of C. acus did not produce sounds under the same experimental conditions. Furthermore, electron micrographs of the sonic muscles from this period indicate atrophied fibres (Parmentier, unpublished data). A seasonal cycle of hypertrophy-atrophy in the sonic muscle has been demonstrated in haddock (Templeman and Hodder 1958), Cynoscion regalis (Connaughton et al. 1997), a Portugese toadfish (Modesto and Canario 2003) and codfish (Rowe and Hutchings 2004).

\section{Damping}

Parmentier and Vandewalle (2003) suggested that the sonic structures might be adapted to compensate for the loss of energy of sonic vibrations as they travel through the thick host tegument, which contains calcareous plates. This hypothesis was tested in a laboratory tank. Because of resonance and reflections, small tanks are quite complex acoustically (Akamatsu et al. 2002) and have the potential to distort sound waveforms. However, because the transmitting and receiving hydrophones were maintained in position, any artefacts from the tank would have equal effects on sound transmitted inside and outside the sea cucumber and should not compromise the current study, which clearly demonstrates that the sea cucumber teguments do not attenuate or modify the frequency spectrum of carapid sounds. Although the signal was weakest at $200 \mathrm{~Hz}$, the long wavelengths associated with low frequency sounds are least likely to be affected by the tegument.

Transparency of the tegument to sound is similar to findings from fish tissue, which has a similar acoustic impedance to water (Von Frish 1936; Dijkgraaf 1960; Tavolga 1971; Popper and Coombs 1980). Although previous sounds from five carapid species were all recorded from within the host (Parmentier et al. 2003a; Lagardère et al. 2005), the current result suggests the intriguing possibility that males could communicate to females outside from the safety of the sea cucumber cavity.

\section{Acknowledgements}

The authors would like to thank J.M. Ouin and his AquaLaboratory team (Institut Halieutique et des Sciences Marines, Tuléar University) for helping to collect $C$. mourlani specimens, and the STARESO team (Calvi, France) for helping to obtain C. acus. D. Lepièce (FUNDP) helped with the sound file acquisition. This work is supported by grant no. 2.4574.01., by 'Bourse de séjour scientifique' no. 2.4558 .03 from 'Fonds National de la Recherche Scientifique de Belgique' and by grants from the 'Fondation Agathon De Potter' (Royal Academy of Belgium, Scientific section).

\section{References}

Akamatsu, T., Okumura, T., Novarini, N., Yan, H. Y. 2002. Empirical refinements applicable to the recording of fish sounds in small tanks. - Fournal of the Acoustical Society of America 112: 3073 3082 .

Connaughton, M. A., Fine, M. L., Taylor, M. H. 1997. The effects of seasonal hypertrophy and atrophy on fiber morphology, metabolic substrate concentration and sound characteristics of the weakfish sonic muscle. - Fournal of Experimental Biology 200: 2449-2457.

Connaughton, M. A., Taylor, M. H., Fine, M. L. 2000. Effects of fish size and temperature on weakfish disturbance calls: implications for the mechanism of sound generation. - Fournal of Experimental Biology 203: 1503-1512.

Courtenay, W. R., McKittrick, F. A. 1970. Sound-producing mechanisms in carapid fishes, with notes on phylogenetic implications. - Marine Biology 7: 131-137.

Dijkgraaf, S. 1960. Hearing in bony fishes. - Proceedings of the Royal Society of London Serie B 152: 51-54.

Eeckhaut, I., Parmentier, E., Becker, P., Gomez da Silva, S., Jangoux, M. 2004. Parasites and biotic diseases in field and cultivated sea cucumbers. In: Lovatelli, C. Conand, Purcell, S. Uthicke, S., Hamel, J.-F. and Mercier, A. (Eds): Advances in Sea Cucumber Aquaculture and Management. - FAO Fisheries Technical Paper. 463: 311-325.

Fine, M. L., Ladich, F. 2003. Sound production, spine locking and related adaptations. In: Kapoor, B. G., Arratia, G., Chardon, M. and Diogo, R. (Eds): Catfishes, pp. 248-290. Science Publishers, Inc., Enfield, $\mathrm{NH}$.

Fine, M. L., Schrinel, J., Cameron, T. M. 2004. The effect of loading on disturbance sounds of the Atlantic croaker Micropogonius undulatus: air vs. water. - Fournal of the Acoustical Society of America 116: 1271-1275.

Hawkins, A. D. 1993. Underwater sound and fish behaviour. In: Pitcher, T. J. (Ed.): Behaviour of Teleost Fishes, pp. 129-169. Chapman \& Hall, London.

Hawkins, A. D., Amorim, M. C. P. 2000. Spawning sounds of the male haddock, Melanogrammus aeglefinus. - Environmental Biology of Fishes 59: 29-41.

Kloss, K., Pfeiffer, W. 2000. Zur biologie des «eingeweidefisches» C. acus (Brunnich, 1768) (Carapidae, Teleostei), mit hinweisen auf eine nich-parasitische ernähung. - Revue Suisse de Zoologie 107: 335-349. 
Ladich, F., Bischof, C., Schleinzer, G., Fuchs, A. 1992. Intra- and interspecific differences in agonistic vocalization in croaking gouramis (Genus: Trichopsis, Anabantoidei. Teleostei). - Bioacoustics 4: 131-141.

Lagardère, J. P., Millot, S., Parmentier, E. 2005. Aspects of sound communication in the pearlfish, Carapus boraborensis and Carapus homei (Carapidae). - Fournal of Experimental Zoology A 303: 10661074.

Lobel, P. S., Mann, D. A. 1995. Spawning sounds of the damselfish, Dascyllus albisella (Pomacentridae), and relationship to male size. - Bioacoustics 6: 187-198.

Markle, D. F., Olney, J. E. 1990. Systematics of the Pearlfish (Pisces: Carapidae). - Bulletin of Marine Science 47: 269-410.

Meyer-Rochow, V. B. 1977. Comparison between 15 Carapus mourlani in a single Holoturian and 19 Carapus mourlani from starfish. - Copeia 1977: 582-585.

Meyer-Rochow, V. B. 1979. Stomach and gut content of Carapus mourlani from starfish and a holothurian. - Annals Zoologica Fennici 16: 287-289.

Modesto, T., Canario, A. 2003. Morphometric changes and sex steroid levels during the annual reproductive cycle of the Lusitanian toadfish, Halobatrachus didactylus. - General and Comparative Endocrinology 131: 220-231.

Myrberg, A. A. Jr, Ha, S. J., Shamblott, M. J. 1993. The sounds of bicolor damselfish (Pomacentrus partitus): predictors of body size and and a spectral basis for individual recognition and assessment. - Fournal of the Acoustical Society of America 94: 3067-3070.

Parmentier, E., Vandewalle, P. 2003. Morphological adaptations of Pearlfish (Carapidae) to their various habitats. In: Val, A. L. and Kapoor, B. G. (Eds), Fish adaptations, pp. 261-276. Oxford \& IBH, India.

Parmentier, E., Vandewalle, P. 2005. Further insight on the Carapini - holothurian relationships. - Marine Biology 146: 455465.

Parmentier, E., Castillo, G., Chardon, M., Vandewalle, P. 2000. Phylogenetic analysis of the pearlfish tribe Carapini (Pisces: Carapidae). - Acta Zoologica 81: 293-306.

Parmentier, E., Chardon, M., Vandewalle, P. 2002. Preliminary study on the ecomorphological signification of the sound-producing complex in Carapidae. In: Aerts, P., D'Août, K., Herrel, A. and Van Damme, R. (Eds): Topics in Functional and EcologicalVertebrate Morphology, pp. 139-151. Shaker Publishing, Maastricht.

Parmentier, E., Vandewalle, P., Lagardère, J. P. 2003a. Sound producing mechanisms and recordings in three Carapidae species. - Fournal of Comparative Physiology A 189: 283-292.
Parmentier, E., Gennotte, V., Focant, B., Goffinet, G., Vandewalle, P. 2003b. Characterization of the primary sonic muscles in Carapus acus (Carapidae): a multidisciplinary approach. - Proceedings of the Royal Society of London Serie B 270: 2301-2308.

Parmentier. E., Mercier, A., Hamel, J. F. 2006. New host and geographical distribution for the pearlfish Carapus mourlani (Carapidae) with a discussion on its biology. - Copeia 2006: 122-128.

Popper, A. N., Coombs, S. 1980. Auditory mechanisms in teleost fishes. - American Scientist 68: 429-440.

Rowe, S., Hutchings, J. A. 2004. The function of sound production by Atlantic cod as inferred from patterns of variation in drumming muscle mass. - Canadian fournal of Zoology 82: 1391-1398.

Smith, C. L. 1964. Some Pearlfishes from Guam, with notes ontheir ecology. - Pacific Sciences 18: 34-40.

Tavolga, W. N. 1971. Sound production and detection. In: Hoar, W. S. and Randall, D. J. (Eds): Fish Physiology, pp. 135-205. Academic Press, New York.

Templeman, W., Hodder, V. M. 1958. Variation with fish length, sex, stage of sexual maturity and season in the appearance and volume of the drumming muscles of the swimbladder in the haddock, Melanogrammus aeglefinus. - Fournal of the Fisheries Research Board of Canada 15: 355-390.

Trott, L. B. 1970. Contribution of the biology of Carapid fishes (Paracanth-Ofterygain: Gadiformes). - University of California Publications in Zoology 89: 1-41.

Trott, L. B., Trott, E. B. 1972. Pearlfishes (Carapidae: Gadiforme) Collected from Puerto Galera, Minobra, Philippines. - Copeia 1972: 839-843.

Trott, L. B. 1981. A general review of the pearlfishes (Pisces, Carapidae). - Bulletin of Marine Science 31: 623-629.

Trott, L. B., and, Olney, J. E. 1986. Carapidae. In: Whitehead, P. J. P., Bauchot, M.-L., Hureau, J.-C., Nielsen, J. and Tortonese, E. (Eds): Fishes of the North-Eastern Atlantic and the Mediterranean., pp. 1172-1176. UNESCO, Paris.

Vanden Spiegel, D., Jangoux, M. 1989. La Symbiose entre poissons Carapidae et Holoturies autour de 1', le de Laing (Mer de Bismark, Papousie Nouvelle Guinée). - Indio-Malayan Zoology 6: 223-228.

Von Frish, K. 1936. Uber den gehörsinn der fische. - Biological Review 11: 210-246.

Wenz, G. M. 1962. Acoustic ambient noise in the ocean: spectra and sources. - Fournal of the Acoustical Society of America 34: 1936-1956.

Zelick, R., Mann, D. A., Popper, A. N. 1999. Acoustic communication in fishes and frogs. In: Fay, R. R. and Popper, A. N. (Eds): Comparative Hearing: Fish and Amphibians, pp. 363-411. Springer, New York. 